\title{
Weonomics
}

Central European Review of Economics \& Finance

Vol. 25, No. 3(2018), pp. 37-49

DOI: $10.24136 /$ ceref.2018.014

Received: 06 February 2018. Accepted: 29 June 2018.

Nalan TERZIOGLU ${ }^{1}$, Turan SUBASAT ${ }^{2}$

\section{IMPORT DEPENDENCY OF EXPORTS AS A CAUSE OF CURRENT ACCOUNT DEFICIT}

The rapid increase in import dependency of exports (IDE) and current account imbalances in many countries over the last two decades led many researchers to argue that they may be correlated and the increase in IDE may be the main cause of current account imbalances. This argument is important because historical evidence suggests that large and persistent current account imbalances often lead to subsequent corrective crisis. If the increase in IDE is a major cause of current account imbalances, reducing it becomes an important policy option to prevent further crisis. While there is a large literature on both global value chains (the main cause of IDE) and current account imbalances, the literature that investigates the link between them is very new and limited. This paper aims to contribute to this limited literature.

Keywords: import dependency of exports, current account imbalances, global value chains, International trade.

JEL Classification Codes: F32, F13, F14, F15, F23.

\section{Introduction}

The rapid increase in import dependency of exports (IDE - facilitated by global value chains) and current account imbalances in many countries over the last two decades (Figure 1) led many researchers to argue that they may be correlated and the increase in IDE may be the main cause of current account imbalances. This argument is important because historical evidence suggests that large and persistent current account

\footnotetext{
${ }^{1}$ Postgraduate student, Mugla Sitki Kocman University.

${ }^{2}$ Professor, Mugla Sitki Kocman University.
} 
imbalances often lead to subsequent corrective crisis. If the increase in IDE is a major cause of current account imbalances, reducing it becomes an important policy option to prevent further crisis $^{3}$.

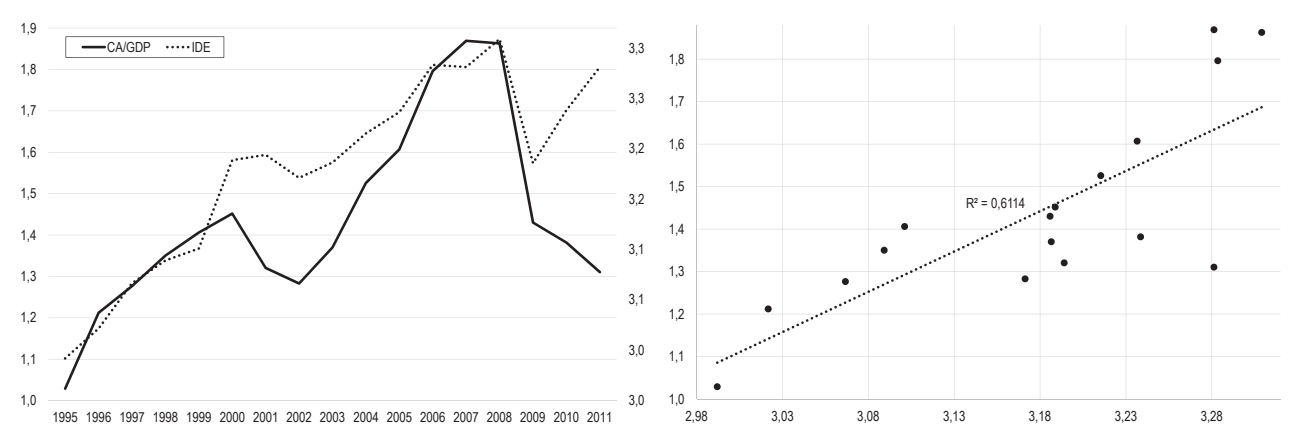

Figure 1. Current account imbalances (\% of GDP) and import dependency of exports (\%)

Note: The chart shows the average absolute value of current account imbalances to GDP ratio for 62 countries.

Figures are in logarithmic scale.

Source: OECD and World Bank.

Identifying the main causes of current account imbalances is a major task. While there is a large literature on both global value chains (the main cause of IDE) and current account imbalances, the literature that investigates the link between them is very new and limited. This paper aims to contribute to this limited literature by focusing on a selection of 62 countries and for the period of 1995 to 2011, which are both determined by the availability of data.

It argues firstly that the increase in IDE and current account imbalances over the last two decades largely resulted from separate sources and the relationship between them is largely coincidental fed by conjunctural factors. While the increase in IDE has been largely driven by enduring global factors (global value chains), the increase in current account imbalances have been due to various temporary conjunctural factors. Secondly, even if (in some countries) there may be a causal relationship between these two variables, the direction of causality (which has not been tested in this limited literature) may run from current account imbalances to IDE. The paper, therefore, concludes that the increase in IDE is not a cause but a consequence of current account imbalances.

\footnotetext{
${ }^{3}$ Sydor (2011) argued that global value chains significantly contributed to the spread of the 2008 crisis while reducing the pain for individual countries. The impact of crisis, however, was greater on trade than GDP.
} 


\section{Import dependency of exports and current account imbalances}

The first notable article in this literature by Georgiadis, Grab, and Trottner (2014) suggests that participation in global value chains should have a positive effect on a country's current account balance because the process involves adding value to imports and then exporting them, which would mathematically increase the trade balance. Brumm, Georgiadis, Grab and Trotter (2016) provide empirical evidence, which show that economies that exhibit stronger Global Value Chain Participation also display larger current account surpluses. Similarly, Cingolani, Felice and Tajoli (2015) argue that while exporting intermediate goods and reimporting finished goods could result in trade deficit, the net effect on trade balance is uncertain since participation in global value chains could also improve efficiency and competitiveness. They find that the current accounts of the EU countries improve (deteriorate) the higher the offshoring to high-income (lowincome) partners implying that the gains in competitiveness are higher (lower). These articles, therefore, claim a positive correlation between higher levels of import dependency of exports and current account surpluses.

Haltmaier (2015), conversely, suggests that higher IDE causes current account deficits but the magnitude of the coefficients signifies a small impact over the sample period. The large increase in the current account imbalances during the 2000s, therefore, cannot solely be explained by the increase in IDE.

The literature on Turkey has been much larger which is not coincidental since Turkey experienced very rapid increase in both variables during the 2000s. Indeed, amongst the 62 countries (that we have data for), Turkey was ranked the fourth in terms of increase in IDE and the first in terms of increase in current account deficit between 1995 and 2011. Many economists in Turkey seem to agree that Turkey's current account deficit has become "structural” and persistent due to the increase in IDE, which has caused trade deficits to become less elastic to the changes in exchange rates (Yeldan 2005, Saygılı and Saygılı 2009, Dogruel and Dogruel 2009). These researchers argue that high levels of IDE significantly reduced the trade equalising impact of real exchange rates. This is mainly because a devaluation, on the one hand, directly increases the profit margins of exporters but, on the other hand, increases the imported import prices for exports and neutralises the profit gains. The net gains for exporters, therefore, are minimal if they exist at all. Also, a devaluation would not always reduce imports, since imports are essential for exports (see Riad et al. 2012).

Ersungur, Ekinci and Takim (2011), for example argued that because exports are insufficient to finance the imports of raw materials, increase in exports stimulates more imports, which increases trade and current account deficits. Similarly, Ozenc \& Altayligil (2013) argue that although parts and components trade increased sharply since 2001, exports failed to keep up with these trends and has led to intensified import dependency, trade and current account deficits. Finally, Dincer \& Yasar (2015) simply asserted that 
increase in import dependency of production and exports led to a deterioration of the trade and the current account balance.

Figure 2 seems to support these arguments in the case of Turkey. Figure 2a shows the development of these variables through time and Figure $2 b$ shows the simple correlation between them. While the figure indicates a very strong correlation between the variables $\left(R^{2}\right.$ is 0.582$)$ for the entire period, the correlation is even stronger $\left(R^{2}\right.$ is 0.863$)$ for the period after 2001 where Turkey experienced a structural break. The strong correlation between these two variables is not specific to Turkey and observed in many other countries. For example, $\mathrm{R}^{2}$ is $66 \%$ in Greece, $80 \%$ in Spain, $86 \%$ in Italy and $92 \%$ in Norway.

a

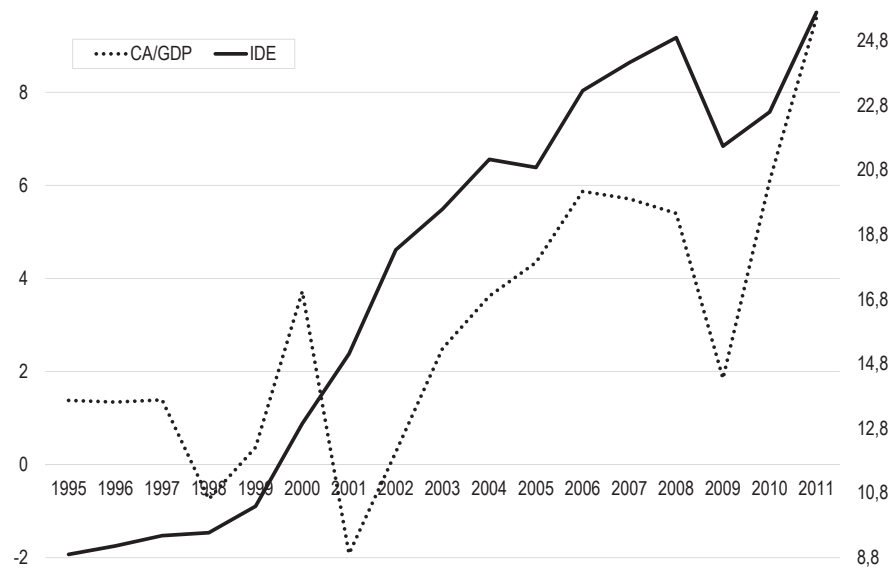

b

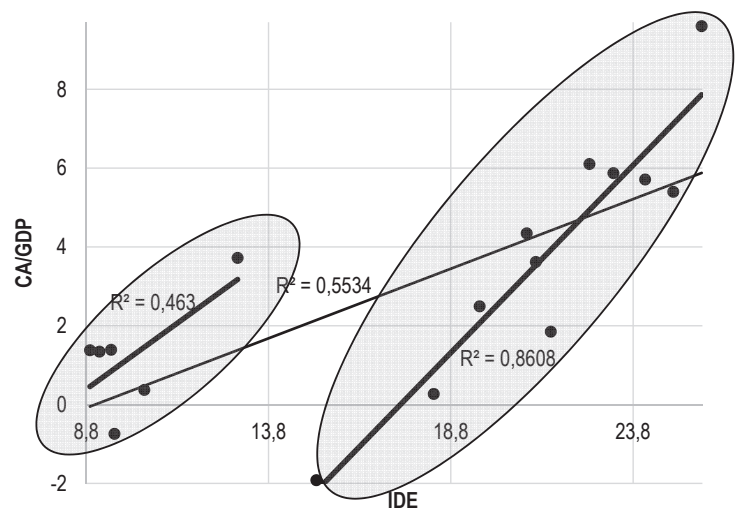

Figure 2. Current account deficits and import dependency of exports in Turkey: a) current account deficits and IDE, b) correlation between current account deficit and IDE

Note: The chart shows "current account deficits” rather than „current account balances”. Normally, a negative (positive) sign in the balance of payments statistics indicates a current account deficit (surplus) but for convenience, we show the current account deficits (surpluses) by a positive (negative) sign.

Source: OECD and World Bank 
The above figures indicate that increase in IDE may indeed be an important determinant of current account deficits. However, the fact that both variables increase together in a given period does not mean that the increase in the IDE is a source of current account deficits due to the following reasons.

First, a third factor may influence both variables. For example, the rapid increase in oil prices from the beginning of the 2000 s to the 2008 crisis may have increased both IDE and current account deficits in many countries.

Second, the increases in IDE and current account deficits may have been driven from different sources, and therefore the relationship between these two variables may have been coincidental determined by conjunctural factors. For example, while the increase in IDE is driven by permanent global factors such as global value chains, the increase in current account deficits is due to some temporary conjunctural factors ${ }^{4}$. The increase in global value chains stemming from the fact that multinational companies have dispersed different stages of their production across countries, which is a more permanent element of globalization. The same cannot be said for current imbalances. Of course, the process of globalization may have created conditions for increased current account instability but they are nevertheless temporary in their nature. It is then possible to argue that the strong correlation observed between these two variables may have been a coincidental relationship due to cyclical factors in the 2000 s.

Third, even if there is a (partial) causality relationship between these two variables, the causality may be running in the opposite direction. In other words, increase in IDE could be a result (not a cause) of current account deficits. For example, the rapid capital inflows into Turkey since 2002, which financed large current account deficits, caused overvaluation of the Turkish Lira, cheapened imports and increased the import dependency of both exports and domestic production. None of the above-mentioned articles tested the causality between these two variables.

Finally, it is theoretically not very meaningful to relate high IDE to current account deficits. For example, assume that Turkey's only export was oil, imported from its Eastern neighbours and re-exported to the Western neighbours with a 20 percent profit margin. In this case, the IDE would be 100 percent but this would not require Turkey to experience any current account deficit. The current account deficit would occur only if Turkey's non-oil imports exceeded the revenue generated from oil re-exports. Increase in IDE would certainly reduce the trade equalising impact of real exchange rates since adjustment takes place mainly outside of the supply chain (Haltmaier 2015). However, it would not necessarily cause current account imbalances.

\footnotetext{
${ }^{4}$ See Subasat (2016) for a review of these conjunctural factors.
} 


\section{Empirical tests}

The above arguments can be tested with the employment of some simple methods. First, if there was a meaningful relationship between high IDE and current account deficit, countries with high IDE would experience high current account deficits whereas current account surplus countries would experience low IDE. Simple observations fail to confirm such a relationship. For example, while Luxembourg experienced the highest IDE rate (59\%) within the 62 countries in 2011 had a current account surplus of $6 \%$, Brazil with a very low IDE rate of $10.7 \%$ (ranked 59 th) experienced $2.9 \%$ current account deficit. It is possible to reproduce similar examples. Singapore, Malaysia, Thailand, Hungary and South Korea had high IDE but current account surpluses while Australia, Colombia, Greece, Cyprus, the USA had low IDE but current account deficits.

Second, a comparison of the average IDE trends in countries that have systematic current account deficits and surpluses with countries that have current account balances produces some meaningful results ${ }^{5}$. As seen in Figure 3, there have been significant increases in the IDE in all three country groups. It is also interesting to note that the countries with current account surpluses have higher average IDEs than the countries that have balanced current accounts. Although there are temporary declines in the early 2000 s and after the 2008 crisis, the increase in IDE continued in all three country groups. Therefore, it is not possible to establish an unambiguous relationship between the IDE and current account deficits. Considering these trends, it is natural to see a conjunctural and accidental relationship between these two variables in the account deficit and surplus countries in the 2000-2008 period, when the current account imbalances (deficits and surpluses) rapidly increased.

Third, the causality between these two variables can be tested by using the same country groups. Table 1 presents the results of this investigation. It is instructive to examine the link between these variables for the 1995-2007 and 2000-2007 periods separately due to the structural breaks observed in many countries during the $2000 \mathrm{~s}$ and exclude the period after 2007 due to the global crisis that has caused yet another structural break. The partial $R^{2}$ values ${ }^{6}$ in the table indicate the power of the correlation between the two variables, and the plus and minus signs indicate the direction of the relationship.

\footnotetext{
${ }^{5}$ We define countries with an average current account deficit or surplus of less than $2 \%$ in the period under consideration (1995-2011) as countries that have balanced current account. Accordingly, countries with larger average current account deficit (surplus) than $2 \%$ are considered as current account deficit (surplus) countries. ${ }^{6}$ The use of partial $R^{2}$ values is essential to assess the direct link between the variables since a trend is added into the correlations to remove the impact of conjectural factors.
} 
a

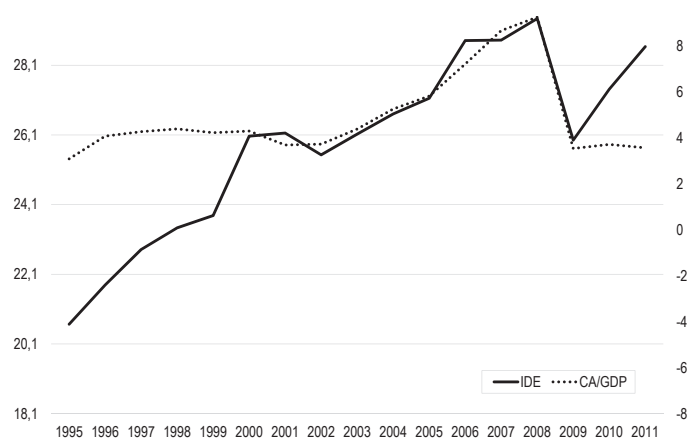

b

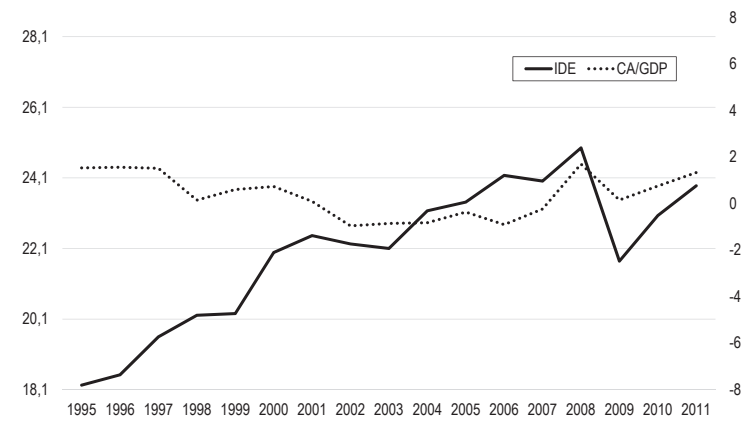

C

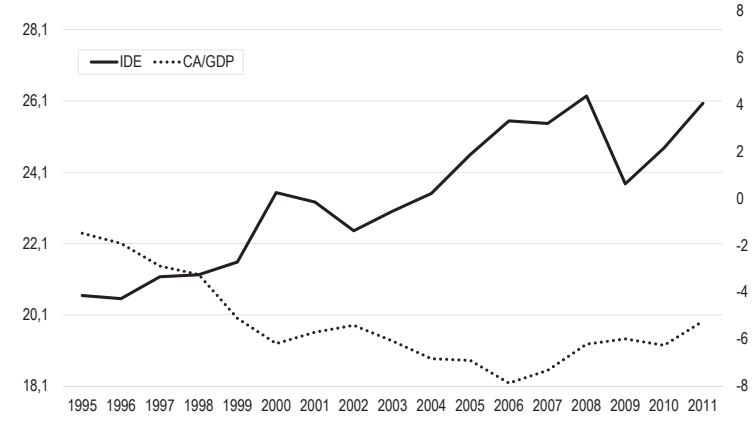

Figure 3. The average current account and import dependency of exports by current account groups: a - current account deficit countries, b - current account balance countries, c - current account surplus countries

Note: The variables reflect the average values of the country groups. See the note in Figure 2 for the signs of current account deficit and surplus.

Source: OECD and World Bank 
Table $1 \mathrm{~A}$ shows that the simple correlations between these variables are quite strong for the current account deficit and surplus countries and especially in the 2000-2008 period, which indicate the conjunctural nature of the relationship. Naturally, the correlation has a negative sign for the current account surplus countries that experienced an increase in their IDE and current account surpluses. The correlations are positive and weaker for the current account balance countries in both periods.

Tables $1 \mathrm{~B}$ and $1 \mathrm{C}$ indicate two-way causality between the variables but for all the groups, causality is stronger from current account to IDE.

Staring from the current account deficit countries, the causality is stronger from IDE to current account deficit with a negative sign (increase in IDE reduced current account deficit) for the 1995-2007 period and is stronger from current account deficit to IDE with a positive sign (increase in current account deficit increased IDE) for the 2000-2007 period.

For the current account balance countries, the causality is stronger from IDE to current account deficit with a negative sign (increase in IDE reduced current account deficit) for the 1995-2007 period and it is stronger from current account to IDE with a positive sign (increase in current account deficit increased IDE) for the 2000-2007 period.

For the current account surplus countries, the causality is stronger from current account to IDE for both periods with negative signs, which implies that an increase in current account surplus tend to cause higher IDE.

The results for all the groups, therefore, contradict the view that increase in IDE is a main cause in current account deficit. Causality is often from current account deficit to IDE and when the causality is from IDE to current account deficit, increase in IDE tends to reduce (not increase) current account deficit.

Table 1. Simple correlation between current account deficit and import dependency of exports and Granger causality test (time series analysis)

\begin{tabular}{|l|c|c|c|c|c|c|}
\hline \multirow{2}{*}{ Partial R square } & \multicolumn{2}{|c|}{ A-simple correlation } & \multicolumn{2}{c|}{ B - CA causes IDE } & \multicolumn{2}{c|}{ C - IDE causes CA } \\
\cline { 2 - 7 } & $1995-2007$ & $\mathbf{2 0 0 0 - 2 0 0 7}$ & $1995-2007$ & $\mathbf{2 0 0 0 - 2 0 0 7}$ & $\mathbf{1 9 9 5 - 2 0 0 7}$ & $\mathbf{2 0 0 0 - 2 0 0 7}$ \\
\hline Current account deficit countries & +0.579 & +0.928 & +0.040 & +0.620 & -0.150 & +0.000 \\
\hline Current account balance countries & +0.168 & +0.193 & +0.168 & +0.656 & -0.210 & +0.074 \\
\hline Current account surplus countries & -0.233 & -0.617 & -0.179 & -0.213 & +0.059 & +0.071 \\
\hline
\end{tabular}

The country case studies for a selection of countries in Table 2 support the results of Table 1. Table $2 \mathrm{~A}$ indicates that the simple correlations are much stronger in the 20002007 period than 1995-2007 period and Tables 2B and 2C indicate a two-way causality between the variables.

In the 1995-2007 period causality is stronger from current account to IDE with positive signs (increase in current account deficit causes higher IDE) for 3 countries 
(Greece, Spain and Portugal). Causality is stronger from IDE to current account with positive sings (increase in IDE causes higher current account deficit) for 2 countries (Turkey and the USA) and with negative signs (increase in IDE causes lower current account deficit) for the other 2 countries (Ireland and the UK). In this period, therefore, for only two countries (Turkey and the USA) support the view that increase in IDE could increase current account deficit but this evidence is only mildly strong for the USA (partial $R^{2}$ is 0.300 ) and very weak for Turkey (partial $R^{2}$ is only 0.062 ).

In the 2000-2007 period causality is stronger from current account to IDE with positive signs (increase in current account deficit causes higher IDE) for four countries (Greece, Spain, Ireland and the UK) and with negative sign (increase in current account deficit causes lower IDE) for one country (Turkey). The causality is stronger from IDE to current account with positive sings (increase in IDE cause higher current account deficit) for two countries (Portugal and the USA) and in both cases the partial $R^{2}$ are lower than 0.200 . In this period, therefore, there is very little support for the view that increase in IDE causes higher current account deficit. Only for the USA IDE seems to increase current account deficit in both periods. The country case studies, therefore, also fail to support the view that increase in IDE causes higher current account deficit.

Table 2. Simple correlation between current account deficit and import dependency of exports and Granger causality test (time series analysis)

\begin{tabular}{|l|c|c|c|c|c|r|}
\hline \multirow{2}{*}{ Partial R } & \multicolumn{2}{|c|}{ A-Simple correlation } & \multicolumn{2}{c|}{ B-CA causes IDE } & \multicolumn{2}{c|}{ C-IDE causes CA } \\
\cline { 2 - 7 } & $1995-2007$ & $2000-2007$ & $1995-2007$ & $2000-2007$ & $1995-2007$ & $2000-2007$ \\
\hline Greece & +0.310 & +0.714 & +0.387 & +0.370 & +0.017 & +0.055 \\
\hline Spain & +0.454 & +0.917 & +0.306 & +0.520 & +0.070 & +0.138 \\
\hline Portugal & +0.012 & +0.841 & +0.001 & +0.062 & +0.000 & +0.183 \\
\hline Ireland & +0.008 & +0.654 & +0.001 & +0.264 & -0.017 & +0.206 \\
\hline Turkey & +0.044 & +0.132 & -0.037 & -0.517 & +0.062 & -0.089 \\
\hline UK & +0.015 & +0.485 & +0.201 & +0.203 & -0.219 & +0.114 \\
\hline USA & +0.013 & +0.035 & +0.007 & +0.028 & +0.300 & +0.198 \\
\hline
\end{tabular}

Finally, the relationship between the variables can also be examined by cross-country analysis. This method aims to find out if countries with high (low) IDE experience high levels of current account deficits (surpluses). The calculations are based on four-year moving averages since year-by-year variations in current account can be very large. Figure 4 illustrates this relationship for a selection of three periods for the countries that experienced long-term current account deficit. In the 1995-1998 period the correlation between the two variables is close to zero $\left(R^{2}\right.$ is 0.0002$)$ and has a negative sign. In the $2000-2003$ period it becomes stronger ( $R^{2}$ is 0.1134 ) with a positive sign, before it becomes weak ( $R^{2}$ is 0.0003$)$ and negative once again in the $2008-2011$ period. 
a

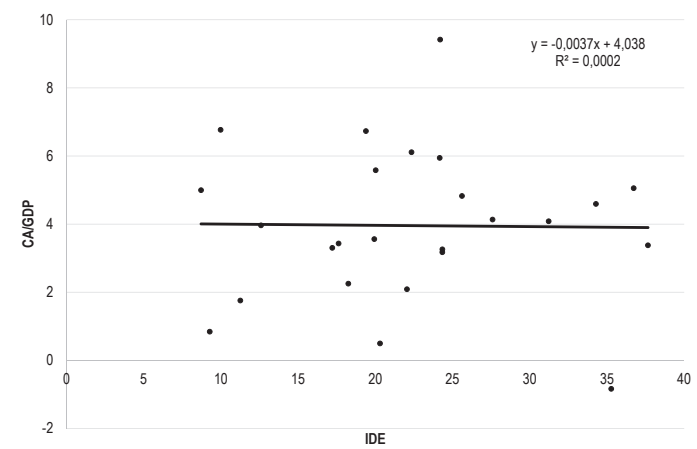

b

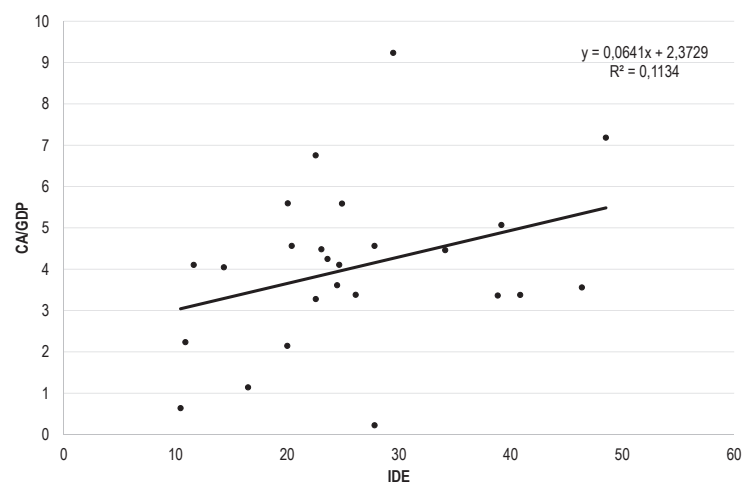

C

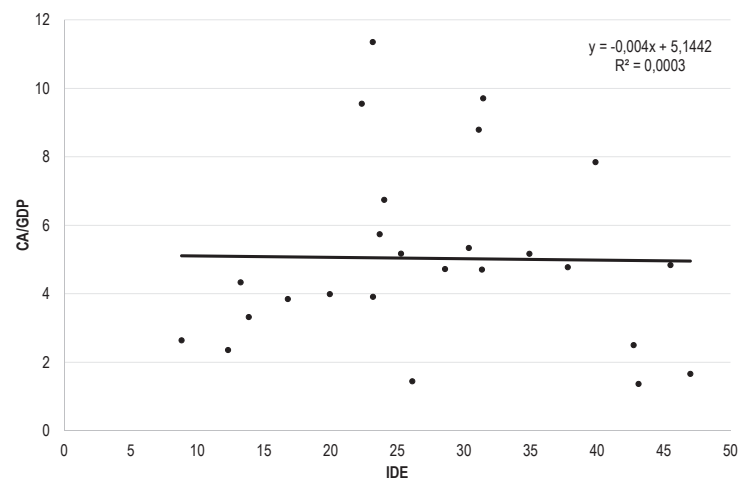

Figure 4. Simple correlations between the current account deficit and import dependency of exports for the current account deficit countries: a - average of 1995-1998, b - average of 2000-2003, c - average of 2008-2011

Figure 5 shows the correlations between the variables for the entire period (19952011) and for all the country groups (all countries, current account deficit countries, current account balance countries and current account surplus countries). The conjunctural 
nature of the relationship between these two variables appears clearly. The correlation starts weak, gets stronger during the early 2000s and gets weaker again, which implies that there is no permanent correlation between these two variables. Interestingly the correlation is stronger and lasts longer for the current account surplus countries.

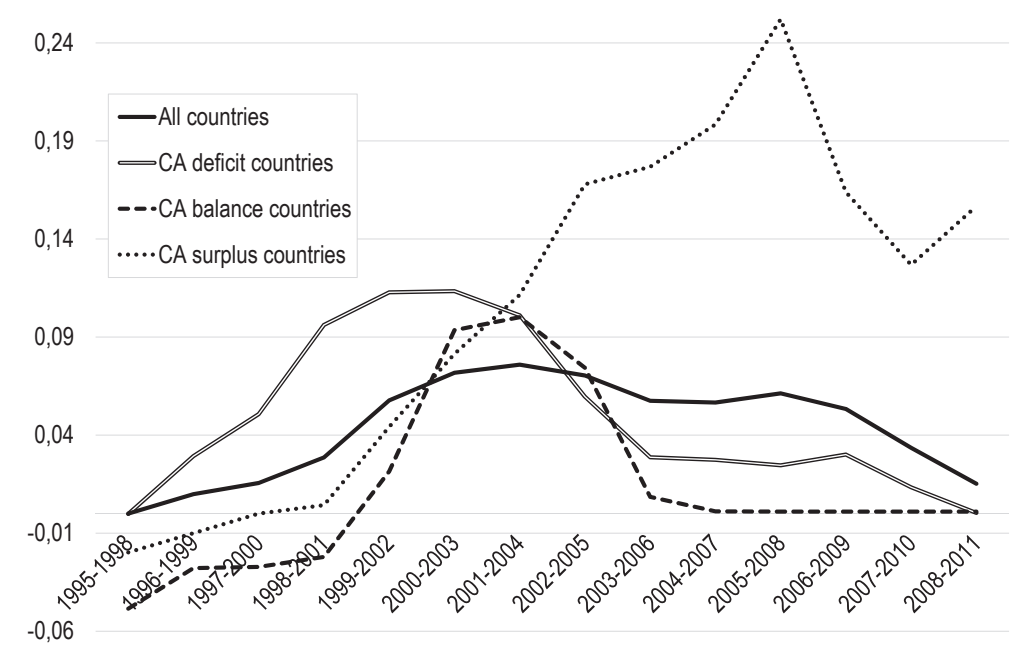

Figure 5. Change in simple correlations between the current account deficit and import dependency of exports for all country groups

\section{Conclusions}

The rapid increase in IDE and current account disequilibrium in many countries in the 2000s has led to the belief that IDE is a major cause of current account disequilibrium, subsequent problems and even crisis. These arguments, however, lacked a solid theoretical basis and empirical support. Our analyses have shown that the relationship between these two variables is conjunctural and therefore temporary. This is because the increase in both variables in the 2000 s resulted from different sources. The increase in IDE is largely due to the global value chains facilitated by the global operations of MNCs, which is a permanent feature of the globalization process. The current account imbalances, however, are conjunctural and temporary problems by their nature. The temporary nature of the link between these variables is well demonstrated by figure 5 where the link is close to zero in the mid-1990s, significantly increases during the 2000s before getting back to zero after the 2008 crisis.

While the theoretical case for a causality from IDE to current account disequilibrium is weak, there may be a weak theoretical case for a causality from current account disequilibrium to IDE since current account deficit is associated with significant appreciation of local currencies which make imported inputs cheaper which may cause 
higher IDE. The causality tests provide evidence for this argument, which suggest that IDE may result from, rather than causing, current account disequilibrium. These findings suggest that IDE result not only from global value chains but also from current account imbalances. The decline in IDE after the 2008 crisis is compatible with these findings. The country studies are also compatible with the above arguments.

\section{References}

Brummy, J., G. Georgiadis, J. Grab \& F. Trottner (2015) , „Global Chain Participation and Current Account Imbalances", December 2015.

Cingolani, I., G. Felice and L. Tajoli (2015), External Imbalances in the European Union and International Fragmentation of Production: Is There a Link?, Centro Studi Luca d'Agliano Development Studies Working Paper No. 386. (Accessed on February 2018), https://papers.ssrn. com/sol3/papers.cfm?abstract_id=2608044

Haltmaier, J. (2015), Have Global Value Chains Contributed to Global Imbalances?, Board of Governors of the Federal Reserve System, International Finance Discussion, Papers 1154.

OECD (2017), Import content of exports (indicator). doi: 10.1787/5834f58a-en (Accessed on 28 November 2017).

The World Bank (2017), World Development Indicators, Washington, D.C.

Özenç, F. K. \& Y. B. Altaylıgil (2013), Determinants of International Fragmentation of Production in Turkey, (Paper presented at the 15th European Trade Study Group Conference in Birmingham, September 12-14, 2013, accessed January 2018. http://www.etsg.org/ETSG2013/ Papers/333.pdf

Ersungur, S.M., E.D. Ekinci \& A. Takim (2011), Türkiye ekonomisinde ithalata bağimliliktaki değişme: girdi-çikti yaklaşimiyla bir uygulama, Atatürk Üniversitesi, İ̈BF Dergisi, 10. Ekonometri ve İstatistik Sempozyumu Özel Sayısı, 2011, accessed January 2018, http://e-dergi. atauni.edu.tr/atauniiibd/article/view/1025007765

Dincer, N.N. and P. Yasar (2015), „Identification of Current Account Deficit: The Case of Turkey”, The International Trade Journal, Volume 29, Issue 1.

Dogruel, F. and S. Dogruel (2009), Türkiye'de Cari Açı: Temel Sorunlar ve Dinamikler, in T. Subasat and H. Yetkiner (eds), Küreselleşen kriz çerçevesinde Türkiye'nin cari açık sorunsalı, Eflatun Yayınlarl: Ankara.

Subasat,T. (2016), 'Conjunctural and policy based causes of the 2008 crisis' in T. Subasat, The Great Meltdown of 2008: Systemic, Conjunctural or Policy-created?, (Edward Elgar: London).

Riad, N., L. Errico, C. Henn, C. Saborowski, M. Saito and J. Turunen (2012), „Changing Patterns of Global Trade", IMF Departmental Papers, No. 12/1, accessed January 2018, https://www. imf.org/external/np/pp/eng/2011/061511.pdf 
Saygıll, M. and H. Sayglı (2009), 'Türkiye'de İhracatın Yapısal Dönüşümü', in T. Subasat and H. Yetkiner (eds), Küreselleşen kriz çerçevesinde Türkiye'nin cari açık sorunsalı, Eflatun Yayınlarl: Ankara.

Sydor, A. (2011), Editor's Overview, in A. Sydor (Ed.), Global Value Chains: Impacts and Implications, Trade Policy Research. Foreign Affairs and International Trade Canada, accessed January 2018, http://www.international.gc.ca/economist-economiste/assets/pdfs/research/ TPR_2011_GVC/02_Editors_Overview_e_FINAL.pdf

Yeldan, E. (2005), „Türkiye Ekonomisi'nde Dış Açık Sorunu ve Yapısal Nedenleri”, Çalışma ve Toplum, 4: 47-60. 